brazilianpoliticalsciencereview

B OOK REVIEW

\title{
Policy Analysis in Brazil: Emergence and Institutionalisation*
}

\author{
Sônia M. Draibe \\ Universidade Estadual de Campinas, Brazil \\ (VAITSMAN, Jeni; MENDES RIBEIRO, José and LOBATO, Lenaura (Ed.) Policy Analysis in Brazil. \\ Bristol: Policy Press, International Library of Policy Analysis Series, 2013)
}

Covernment decisions are taken based on circumstantiated studies and analyses

Jof the policy in question. These studies, backed up by theory, research and good practices, indicate the alternatives available and their consequences, thus allowing the decision maker to choose with knowledge and confidence the most convenient programme or policy for the objectives proposed.

Does this ideal, modern, rational world correspond to the practices of decision-makers? Is this comfortable situation, in which validated options are offered in order to inform decisions taken in the public and private spheres, the norm? That is not always the case. It is even less true if one considers all countries.

This is because this ideal situation assumes that certain "normal" prerequisites will be in place, i.e. a degree of evolution in the process of modernisation of the state and a legalinstitutional framework that requires and legitimises processes of the type described; in short, the availability of technical and bureaucratic personnel endowed with competence and ability to manage the methods and instruments of policy analysis. However, such conditions cannot be created overnight. They result from long and complex processes of institutional development and the modernisation of organisations and procedures. Even then, it still takes time for those practices to become widespread and take root.

What are the characteristics of the Brazilian practice of public policy analysis?

This is the question that Policy Analysis in Brazil attempts to answer. The 18-chapter collection is edited by Jeni Vaitsman, José M. Ribeiro and Lenaura Lobato and was published in mid-2013 by Policy Press, introducing its International Library of Policy Analysis Series.

It is a timely publication, with work of very good quality, by 27 authors of renowned experience and competence. This is also true of the editors, Jeni Vaitsman and José Mendes Ribeiro, senior researchers and professors of the National School of Public Health of the Oswaldo Cruz Foundation in the area of Public Policy. Lenaura Lobato is a professor at the Federal Fluminense University, where she coordinates the Centre for Social Policy Evaluation and Analysis.

The Brazilian experience is examined in different domains and dimensions, in articles that blend together research and reflection. The compilation is organised in four parts. 
Historical and methodological questions are the topics of Part I. The professionalisation of policy analysis in Brazil (VAITSMAN, MENDES RIBEIRO and LOBATO, 2013) is examined in the light of the wider context of modernisation of the state and development of a professionalised bureaucracy, recruited on merit, knowledge and technical specialisation (SOUZA, 2013). These conditions were necessary but not sufficient for the emergence, diffusion and dissemination of the policy analyst profession. This only happened when the shape of the state and forms of governance changed, with the 1988 Constitution and more transparent and participative deliberative processes.

Policy analysis is a recent disciplinary and professional field, which did not develop with its own methodologies and styles, particularly not with those enshrined by the AngloSaxon tradition. In Brazil, it initially leant on the economic style of analysis (for example, cost-benefit analysis) and, after 1988, on the socio-political style of analysis, incorporating methodological instruments from the social sciences (ANDREWS, 2013).

The studies in Part II examine the production of policy analyses of bodies of the federal executive (MENDES RIBEIRO and INGLEZ-DIAS, 2013; PAES DE SOUZA and HELLMAN, 2013), state governments (FILGUEIRAS and ROCHA, 2013), municipal governments (FARAH, 2013), of public banks such as the BNDES [Banco Nacional de Desenvolvimento Econômico - Brazilian Bank for Development] (VELASCO and CASTELAR PINHEIRO, 2013) and of the Brazilian Congress (SANTOS, 2013).

With a special focus on the relationship between public policy and politics, Part III examines policy analysin different contexts: the cases of the Conselho Nacional de Assistência Social [CNAS - National Council for Social Assistance] (VARGAS CÔRTES, 2013), social movements (HORA GÓIS, 2013) and other civil society associations, such as those actively involved in the shaping of a national policy to fight AIDS (MASSARD DA FONSECA and BASTOS, 2013), the media (LATTMAN-WELTMAN, 2013), political party (DANTAS NETO, 2013) and business associations (BOSCHI, 2013).

Part IV is dedicated to the production of policy analysis in universities, research institutes and think-tanks. The latter are few and recent, having generally been established with a certain distance from political activity and social movements (TEIXEIRA, 2013).

The case of universities is different. The strong epistemic community involved in the institution of a national health policy, for example, mobilised in the 1980s the specialist's academic production, successful in creating a national health system according to the principles it extolled (ROSÁRIO COSTA, 2013). The widening of university activity, which involved studies on the evaluation, formulation and implementation of policies, strengthened the role of academia in the field (BATISTA, 2013). From the end of the 1980s, the training of public policy analysts also increased, with subjects and postgraduate programmes multiplying, giving public policy greater visibility and prominence (HOLANDA and SIQUEIRA, 2013).

The book's definitions, perspective and form ensure its unity and homogeneity. Among the many definitions of policy analysis, the authors chose the one that sees it as the area of public policy studies whose aim is to produce technical-scientific substantiation and alternatives for decision-makers. Differently from the analysis of policy, which is analytical and descriptive, it deals with analysis for policy, which is prescriptive and propositional (For this definition and others, see BARDACH, 2011; BREWER and DELEON, 1983; DROR, 1967; DUNN, 1994; FISCHER and FORESTER, 1992; FISCHER, GERALD and SIDNEY, 2007; GUY PETERS and PIERRE, 2006; HAWLET, RAMESH and PERL, 2009; WEIMER and VINING, 1992).

The articles commonly adopt a simultaneously contemporary and historical perspective, although their approaches and styles of political analysis may vary. In each one 
of the experiences analysed, the authors make a quick historical assessment, situating today's practice in a more long-sighted perspective.

Still regarding form, it is worth noting that the collection is composed of short, concise chapters, a strategy that allows it to cover the wide range of topics mentioned in a coordinated and coherent fashion.

A strong thesis permeates the entire compilation and frames the different studies: in Brazil, policy analysis, understood by the authors as the production of studies for policymakers, is a recent practice. Examples can be found here and there in the past and up until the 1980s, but it was only with democratisation and after the institutional innovations introduced by the 1988 Constitution, and especially from the 2000s onwards, that it actually became widespread as a routine procedure by government bodies.

This is one of the sub-processes of modernisation of the Brazilian State, in which several technical and bureaucratic careers took shape, processes of recruitment based on merit were institutionalised and the practice of basing decisions on technical studies of diagnostics and forecasting of results became generalised. The state became more democratic and transparent because it informed more, and the decision-making system became more participative, with an increase of councils and consultation systems.

The thesis is generally correct but, when confronted with the particularities of the Brazilian experience, comes up against a few difficulties. These difficulties, in my view, result from both a restricted definition of policy analysis and the proposed periodisation for the modernisation of the state and the practice of policy analysis as a basis for decisions.

The pattern of modernisation of the Brazilian State was neither linear nor homogeneous. From the 1930s onwards, in the state structure, there were pockets of modernity living alongside an environment controlled by patrimonialism, nepotism and favouritism among sectors, companies and institutions. This is a classical thesis and has been well defended and argued by many (GRAHAN, 1968; JAGUARIBE, 1962; LAFER, 1970; MARTINS, 1973). These pockets of modernity were the mining engineers active in the creation of Petrobrás; the DASP (Departamento Administrativo do Serviço Público - Civil Service Administration Bureau), in 1938; the BNDE, later known as BNDES, in 1952; the economic advisors of President Vargas (2nd government); the executive groups of the Kubitschek period; and later, during the 1964-1985 military period, the IPEA (Instituto de Pesquisa Econômica Aplicada -Institute for Applied Economic Research), the Banco Central (Central Bank) and so many other bodies - all of them with the function of providing technical assistance to the decisionmakers. Between 1980 and 1990, technical areas of the traditional ministries and systems of policy assessments, such as the one implemented by the INEP (Instituto Nacional de Estudos e Pesquisas Educacionais - National Institute of Educational Studies and Research) also grew and were able to back up important decisions, such as the implementation of the SUS (Sistema Único de Saúde - Unified Health System), of the Statute of the Child and the Adolescent, of the FUNDEF (Fundo de Manutenção e Desenvolvimento do Ensino Fundamental de Valorização do Magistério -Fund for Development of Primary Education and Improvement of theTeaching Profession) and the pension reform. Not to mention the now traditional elaboration of the EIA/RIMA (Estudo de Impacto Ambiental/Relatório de Impacto Ambiental - Environmental Impact Study/Environmental Impact Report) by independent institutions for the benefit of investments with likely environmental impacts.

It could be that another narrative, operating with a different periodisation from that of Policy Analysis in Brazil, might see the Brazilian experience prior to the 2000s through another lens, assigning it a more defining role in the introduction and institutionalisation of 
the practice of public policy analysis in the country. That is, one that would reconstitute the particular periodisation of the field of public policy in Brazil, and detect periods of emergence, development and consolidation.

In my opinion, the strict definition of policy analysis makes it difficult to retrieve the particularity of such an experience. In Brazil, policy analysis and policy evaluation were mingled in academic production, whose main "clients" are the governments, from the outset, and remain so today. Policy recommendations and alternatives were and still are a part of this activity, which grew significantly in the 1980s.

My observations in no way diminish the importance of this publication - on the contrary.

A reasonable criterion for evaluating a compilation such as this is whether it is sufficiently comprehensible and wide-ranging for the mixed readership - tutors, students and policy analysts - for which it is written and whether it is comprehensible, inclusive and an easy and relevant guide to the field, indicating key concepts, main axes and cleavages, and paths for furthering future knowledge.

Policy Analysis in Brazil meets these criteria very well. The chapters provide a clear and accessible analysis of the main concepts of the disciplinary field, as well as offering good insights into the reach of public policy analysis in specific areas, indicating the resources mobilised, the typical actors involved and styles of analysis. The book will no doubt enrich the public policy bibliography and considerably benefit those students and professionals interested in familiarising themselves with the Brazilian practice and intellectual production of this field of public policy.

\section{References}

ANDREWS, Christina (2013), Policy Analysis Styles in Brazil. In: VAITSMAN, Jeni; MENDES RIBEIRO, José and LOBATO, Lenaura (Ed.). Policy Analysis in Brazil. Bristol, Policy Press, International Library of Policy Analysis Series.

BARDACH, Eugene (2011), A Practical Guide for Policy Analysis: The Eightfold Path to More Effective Problem Solving, 4th edition, CQ Press.

BATISTA, Cristiane (2013), Policy analysis by academic institutions in Rio de Janeiro state. In: VAITSMAN, Jeni; MENDES RIBEIRO, José and LOBATO, Lenaura (Ed.). Policy Analysis in Brazil. Bristol, Policy Press, International Library of Policy Analysis Series.

BOSCHI, Renato. R. (2013), Business associations and public policy analysis. In: VAITSMAN, Jeni; MENDES RIBEIRO, José and LOBATO, Lenaura (Ed.). Policy Analysis in Brazil. Bristol, Policy Press, International Library of Policy Analysis Series.

BREWER, G. and DeLeon, P. (1983), The Foundations of Policy Analysis, Homewood, Il., Dorsey.

CORTES, Soraya Vargas (2013), Brazil's National Social Assistance Policy Council (CNAS) and the policy community supporting social assistance as a right. In: VAITSMAN, Jeni; MENDES RIBEIRO, José and LOBATO, Lenaura (Ed.). Policy Analysis in Brazil. Bristol, Policy Press, International Library of Policy Analysis Series.

DANTAS NETO, Paulo Fábio (2013), Parties and public policy: programmatic formulation and political processing of constitutional amendments. In: VAITSMAN, Jeni; MENDES RIBEIRO, José and LOBATO, Lenaura (Ed.). Policy Analysis in Brazil. Bristol, Policy Press, International Library of Policy Analysis Series.

DROR, Y. (1967), Policy analysts: a new professional role in government service, Public Administration Review, Vol. 27, № 03, p.198.

DUNN, W. (1994), Public policy analysis: an introduction. 2nd ed., Prentice-Hall, Englewood Cliffs, NJ.

FARAH, Marta (2013), Policy analysis at the municipal level of government. In: VAITSMAN, Jeni; MENDES RIBEIRO, José and LOBATO, Lenaura (Ed.). Policy Analysis in Brazil. Bristol, Policy Press, International Library of Policy Analysis Series. 
FILGUEIRAS, Cristina de Almeida and ROCHA , Carlos Alberto (2013), Production of policy-related information and knowledge in Brazil: the state government agencies. In:VAITSMAN, Jeni; MENDES RIBEIRO, José and LOBATO, Lenaura (Ed.). Policy Analysis in Brazil. Bristol, Policy Press, International Library of Policy Analysis Series.

FISCHER, F. And Forester, J. (Eds.)(1993), The Argumentative Turn in Policy Analysis and Planning, Duke University Press.

FISCHER, Frank; MILLER, Gerald J. and SIDNEY, Mara S.(Ed.)(2007), Handbook of Public Policy Analysis. Theory, Politics and Methods. New York. CRC Press. Taylor\& Francis Group.

GRAHAM, Lawrence S. (1968), Civil service reform in Brazil. Austin: University of Texas Press.

HAWLET, M; RAMESH, M. and PERL, Anthony (2009), Política Pública. Seus ciclos e subsistemas. Rio de Janeiro: Ed Campus.

HOLLANDA, Eliane and SIQUEIRA, Sandra (2013), Postgraduate instruction and policy analysis training in Brazil. In: VAITSMAN, Jeni; MENDES RIBEIRO, José and LOBATO, Lenaura (Ed.). Policy Analysis in Brazil. Bristol, Policy Press, International Library of Policy Analysis Series.

HORA GÓIS, João B. 2013. Policy analysis in non-governmental organizations and the implementation of pro-diversity policies. In: VAITSMAN, Jeni; MENDES RIBEIRO, José and LOBATO, Lenaura (Ed.). Policy Analysis in Brazil. Bristol, Policy Press, International Library of Policy Analysis Series.

JAGUARIBE, Hélio (1962), Desenvolvimento econômico e desenvolvimento político. Rio de Janeiro: Fundo de Cultura.

LAFER, Celso (1970), The planning process and political system in Brazil: a study of Kubitschek's target plan (1956-1961). Cornell University (Doctoral thesis).

LATTMAN-WELTMAN, Fernando (2013), Media and policy analysis in Brazil: the process of policy production, reception and analysis through the media. In: VAITSMAN, Jeni; MENDES RIBEIRO, José and LOBATO, Lenaura (Ed.). Policy Analysis in Brazil. Bristol, Policy Press, International Library of Policy Analysis Series.

MARTINS, Luciano (1973), Pouvoir politique et développement économique, structures de pouvoir et système de décisions au Brésil. Université René Descartes (Doctoral thesis).

MASSARD DA FONSECA, Elize and BASTOS, Francisco I. (2013), A Brazilian response to the HIV/AIDS epidemic: integrating prevention and treatment. In: VAITSMAN, Jeni; MENDES RIBEIRO, José and LOBATO, Lenaura (Ed.). Policy Analysis in Brazil. Bristol, Policy Press, International Library of Policy Analysis Series.

MENDES RIBEIRO, José and INGLEZ-DIAS, Aline (2013), Policy analysis and governance innovations in the federal government. In: VAITSMAN, Jeni; MENDES RIBEIRO, José and LOBATO, Lenaura (Ed.). Policy Analysis in Brazil. Bristol, Policy Press, International Library of Policy Analysis Series.

PAES-SOUZA, Romulo and HELLMAN, Aline (2013), Policy monitoring and evaluation systems: recent advances in Brazil's federal public administration. In: VAITSMAN, Jeni; MENDES RIBEIRO, José and LOBATO, Lenaura (Ed.). Policy Analysis in Brazil. Bristol, Policy Press, International Library of Policy Analysis Series.

PETERS, Guy B. and PIERRE, Jon (2006), Handbook of Public Policy. London: Sage Publications.

ROSÁRIO COSTA, Nilson (2013), Expert community and sectoral policy: the Brazilian Sanitary Reform. In: VAITSMAN, Jeni; MENDES RIBEIRO, José and LOBATO, Lenaura (Ed.). Policy Analysis in Brazil. Bristol, Policy Press, International Library of Policy Analysis Series.

SANTOS, Fabiano Guilherme M. (2013), The role of the Brazilian legislature in the public policy decision making process. In: VAITSMAN, Jeni; MENDES RIBEIRO, José and LOBATO, Lenaura (Ed.). Policy Analysis in Brazil. Bristol, Policy Press, International Library of Policy Analysis Series.

SOUZA, Celina (2013), Modernization of the state and bureaucratic capacity-building in the Brazilian Federal Government. In: VAITSMAN, Jeni; MENDES RIBEIRO, José and LOBATO, Lenaura (Ed.). Policy Analysis in Brazil. Bristol, Policy Press, International Library of Policy Analysis Series.

TEIXEIRA, Tatiana (2013), Brazilian think-tanks: between the past and the future. In: VAITSMAN, Jeni; MENDES RIBEIRO, José and LOBATO, Lenaura (Ed.). Policy Analysis in Brazil. Bristol, Policy Press, International Library of Policy Analysis Series.

VAITSMAN, Jeni; LOBATO, Lenaura and ANDRADE, Gabriela R. B. (2013), Professionalisation of policy analysis in Brazil. In: VAITSMAN, Jeni; MENDES RIBEIRO, José and LOBATO, Lenaura (Ed.). Policy Analysis in Brazil. Bristol, Policy Press, International Library of Policy Analysis Series.

VELASCO, Licinio and CASTELAR PINHEIRO, Armando (2013), Privatization and policy decision making in Brazil. In: VAITSMAN, Jeni; MENDES RIBEIRO, José and LOBATO, Lenaura (Ed.). Policy Analysis in Brazil. Bristol, Policy Press, International Library of Policy Analysis Series.

WEIMER, D. and VINING, A. (1992), Policy Analysis: Concepts and Practice, Prentice Hall, Englewood Cliffs, NJ. 